Sanja Čupić ${ }^{1}$

izv. prof. dr. sc. Vinko Muštra²

\title{
REZILIJENTNOST REGIONALNE ZAPOSLENOSTI, NEZAPOSLENOSTI I PARTICIPACIJE U REPUBLICI HRVATSKOJ
}

\author{
Izvorni znanstveni rad / Original scientific paper \\ UDK/UDC: 314.93 \\ DOI: 10.51650/ezrvs.15.1-2.2 \\ Primljeno / Received: 5/3/2021 \\ Prihvaćeno / Accepted: 10/6/2021
}

\begin{abstract}
Značajne turbulencije globalnog gospodarstva u recentnom razdoblju su imale heterogene posljedice na lokalnoj i regionalnoj razini. Navedeno je zaokupilo pažnju znanstvene zajednice, rezultirajući s promoviranjem koncepta rezilijentnosti kao sposobnosti određenog sustava u prilagodbi tijekom i nakon određenog negativnog šoka. Analiza rezilijentnosti tržišta rada na županijskoj razini u Republici Hrvatskoj obuhvatila je analizu otpornosti i oporavka navedenih tržišta i to kroz prizmu zaposlenosti, nezaposlenost i participacije. Empirijski rezultati su istaknuli Zadarsku županiju kao najrezistentnije regionalno tržište rada u RH. Ujedno je heterogenost preostalih rezultata upućivala na svu kompleksnost odnosa na tržištu rada, kao i jasnu potrebu za daljnjim istraživanjima.
\end{abstract}

Ključne riječi: rezlijentnost, zaposlenost, nezaposlenost, participacija, regije, Republika Hrvatska.

\section{Uvod}

Tržište rada ne predstavlja samo jedno od najkompleksnijih i najosjetljivijih tržišta, već i fenomen koji snažno zrcali svu složenost socio-ekonomskih odnosa. Slijedom navedenog, tržište rada može se odrediti i kao polazišnu točku ocjene stanja nacionalnog gospodarstva i društva u cjelini, posebno uvažavajući nezaobilaznu ulogu zbivanja na tržištu rada u postizanju blagostanja i što višeg životnog standarda njenih građana.

Niz barijera prilikom ulaska i izlaska iz zapošljavanja, niska mobilnost, strukturne nepodudarnosti te razmjerno visoki troškovi rada s nizom nepovoljnih ishoda su jedni od glavnih obilježja nefunkcionalnog tržišta rada u Republici Hrvatskoj. (npr. Bejaković i Mrnjavac, 2018; Tomić i Žilić, 2020; Håkansson Gladoić i Bejaković, 2020).

${ }^{1}$ Ekonomski fakultet Sveučilišta u Splitu

2 Ekonomski fakultet Sveučilišta u Splitu; e-mail: vmustra@efst.hr 
S druge strane, svjetska gospodarska kretanja u 21 stoljeću su obilježena turbulentnim zbivanjima. Na globalnoj razini prvenstveno uzrokovani financijskom krizom te recentnom zdravstvenom pandemijom. Pojedina gospodarstva su dodatno uzdrmana specifičnim nacionalnim šokovima, s iznimno heterogenim posljedicama na lokalnoj i regionalnoj razini ( Nyström i Ros, 2017; Nyström, 2017; Giannakis i Bruggeman, 2020). Sve navedeno je nagnalo sve ključne dionike i sveukupnu javnost da pozicioniraju zbivanja na tržištu rada na pijedestal njihovog interesa u trenucima velikih globalnih šokova. Na tom tragu je i promoviran koncept rezilijentnosti tržišta rada, kao metodološki okvir pogodan za tumačenje sposobnosti lokalnih i regionalnih tržišta rada da adekvatno reagiraju u vremenima velikih šokova i turbulencija. (npr. Chapple, Lester, 2010; Bigos et al, 2013; Diodato i Weterings, 2015).

Usprkos prepoznatoj važnosti navedenog fenomena u svjetskim okvirima, isti je bio gotovo u potpunosti zanemaren u Republici Hrvatskoj. Štoviše, uvažavajući iznimne razlike ključnih obilježja i ishoda tržišta rada na lokalnoj i regionalnoj razini , pitanje rezilijentnosti tržišta rada na regionalnom nivou zaslužuje posebnu pažnju.

Slijedom navedenog ovaj rad pokušava rasvijetliti obilježja rezilijentnosti tržišta rada u Republici Hrvatskoj na regionalnoj razini za period od 2008 do 2018. Za potrebe navedenog cilja, u sljedećom poglavlju se predstavljaju osnovne teorijske odrednice pojma rezilijenosti tržišta rada. Treće poglavlje je usmjereno na predstavljanje podatkovne osnove, metode te empirijske rezultate, dok četvrto poglavlje u formi zaključka naglašava najvažnije reperkusije rada.

\section{Teorijske odrednice rezilijentnosti tržišta rada}

Sam pojam rezilijentnosti (engl. resilience) potječe od latinskog izraza „resilire”, a što znači odskočiti ili odbijati te je široko upotrebljavan u mnogim znanstvenim područjima. Usprkos širokoj primjeni, samo razumijevanje obuhvata pojma nije ostvarilo konsenzus, rezultirajući s tri glavna metodološka pravca u definiranju pojma: tehnički (engl. engineering), ekološki (engl. ecological) i adaptivni (engl. adaptive).

Tehnički pristup promoviran od strane Hollinga (1973.) prvenstveno naglašava otpornost sustava na određene šokove i njegov povratak u ravnotežu koja je prevladavala prije poremećaja. Ekološka rezilijentnost pak se definira prema razini šokova koje sustav može prihvatiti prije nego promijeni svoj oblik, funkciju ili položaj (Martin, 2012.). Dakle, što je veći šok potreban da bi promijenio strukturu i funkciju sustava, to je sustav rezilijentniji (Simmie i Martin, 2010). Treći pak pravac, poznat pod nazivom adaptivna rezilijentnost naglašava sposobnost prilagodbe sustava na određene vanjske šokove, a bez negativnog utjecaja na budući razvojni proces (Martin, 2012).

Važno je istaknuti kako sva tri pristupa se određuju u odnosu na vanjski egzogeni šok, ali i kako je u procesu razumijevanja pojma potrebno zahtijevaju uvažavanje četiri međusobno povezane dimenzije. Prva dimenzija je otpornost (engl. resistance), odnosno ranjivost ili osjetljivost sustava na šok. Oporavak (engl. recovery) se pak odnosi se na brzinu i stupanj oporavka nakon negativnog događaja. Treća dimenzija se bavi razmjerom strukturalnog preusmjeravanja sustava (engl. re-orientation). Četvrta dimenzija odnosi se na stupanj obnove (engl. renewal) ili nastavljanja razvojne putanje prije šoka.

Sa sve intenzivnijim i izraženijim turbulencijama u gospodarskoj domeni, pojam rezilijentnost biva prepoznat i u ekonomskoj znanosti koja ga prvenstveno definira kao sposobnost 
sustava u suočavanju s promjenama te mogućnosti daljnjeg nastavka razvitka (Simmie i Martin, 2010; Martin 2012; Martin and Sunley, 2015; Giacometti et al., 2019) te stavljajući naglasak u empirijskim radovima na dimenzijama otpornosti i oporavka (npr. Fingleton et al., 2015; Faggian et al., 2018, Muštra et al, 2020).

Navedena sposobnost sustava se pak najizravnije, najizraženije ali i najdugoročnije reflektira na tržištu rada, posebice u vidu šokova koji značajno slabe funkcioniranje tržišta rada (Bigos et al. 2013). Upravo dramatični promjene na tržištu rada diljem svijeta, kao posljedica ekonomskih šokova, sugeriraju važnost razumijevanja osobina rezilijentnosti navedenog tržišta.

Prema OECD (2012a), razina rezilijentnosti na tržištu rada može se mjeriti kroz promjenu društvenih troškova i dobrobiti radnika. Naime, to uključuje promjene u stopi nezaposlenosti, zaposlenosti, ostvarivanju prihoda te u načinu raspodjele navedenih rezultata.

Međutim, za potpuno razumijevanje i procjenu rezilijentnosti na tržištu rada ključno je uzeti u obzir vremenska ograničenja koja uokviruju sam pojam, ali početni strukturni kontekst (više u Bigos et al., 2013). Isti autor u definiranju konteksta prepoznaje institucionalne, socio-ekonomske i demografske uvjete. Institucionalni uvjeti obuhvaćaju sve aspekte regulacije radnog odnosa poput pravnog okvira za standarde na poslu, utvrđivanja visine (minimalne) plaće, sindikalno povezivanje, aktivne politike tržišta rada s posebnim osvrtom na oporezivanje rada.

Pod socio-ekonomskim uvjetima se prvenstveno uvažavaju regionalne razlike po pitanju strukture poslovnih subjekata te ostvarenih razvojnih razina. Struktura poslovnih subjekata uvažava različitost i po pitanju zastupljenosti pojedinih veličina poduzeća, ali i gospodarskih djelatnosti. Veća prisutnost malih i srednjih poduzeća se prepoznaje kao značajan faktor rizika u kriznim vremenima, ali i kao potencijalna lokomotiva brže prilagodbe i oporavka. Struktura prema gospodarskim djelatnostima svoju relevantnost opravdava kroz "cikličku stabilnost" pojedinih gospodarskih djelatnosti. Naime, određene djelatnosti imaju izraženije reakcije na različite vrste šokova, a što se uvelike prelijeva i na tržište rada. Slijedom navedenog, prostorne cjeline koje imaju prisutne različite gospodarske djelatnosti s naglaskom na one s manjom osjetljivošću na egzogene šokove, karakterizira značajnija rezilijentnost i tržišta rada (Bigos et al., 2013).

Demografski aspekti također predstavljaju značajnu odrednicu rezilijentnosti tržišta rada. Naime, veći udio, ali i sam veći broj mlađeg stanovništva, reflektira i veću mogućnost prilagodbe u novonastalim uvjetima. Prednost u prilagodbi se ogleda i kroz samu mogućnost promjene uvjeta rada, ali i samog radnog mjesta, kao i savladavanja novih vještina i znanja potrebnih kao odgovor na eksterne šokove (OECD, 2012b)

Slijedom navedenog Bigos et al. (2013), rezilijentnosti tržišta rada definira kao sposobnost tržišta rada da se odupre, izdrži ili se oporavi od izazova prilagođavanjem putem inoviranja ili preusmjeravanjem svojih struktura kako bi se održalo ili poboljšalo njegovo stanje prije nastupanja šoka.

U kojoj su mjeri navedeni atributi rezilijentnosti prisutni u Hrvatskoj je dosad slabo istražen pojam. Postojeća istraživanja su prvenstveno bila usmjerena na analize na nacionalnojrazini i to tema poput uključivanja i izlazak svijet rada, karakteristika nezaposlenosti, spolne nejednakosti, razlike u plaćama u privatnom i javnom sektoru, nerazmjer između ponude i potražnje za specifičnim vještinama, kao i učinaka odgovarajućih ekonomskih politika i 
kolektivnog ugovaranja (npr. Bejaković i Mrnjavac, 2018, Tomić i Žilić, 2020; Håkansson Gladoić i Bejaković, 2020, Ledić i Rubil, 2021).

S druge strane, usprkos određenom istraživačkom interesu za analizu učinka kriznih razdoblja na tržite rada (npr. Nestić i Tomić, 2018, Håkansson Gladoić i Bejaković, 2020 ), kao i uvažavanju prostorne dimenzije (npr. Nestić et al, 2018), zajedničko promatranje prostorne heterogenosti po pitanju regionalne rezilijentnosti tržišta rada je ostalo zanemareno.

\section{Podaci, metodologija i rezultati}

\subsection{Podaci}

U analizu je uključeno 20 županija Republike Hrvatske te Grad Zagreb kao samostalna, jedinstvena teritorijalna i upravna jedinica. Obuhvaćeno je vremensko razdoblje od 2008. do 2018. godine, koje odgovara razdoblju prije, tijekom i nakon globalne financijske i ekonomske krize. Ispitivanje rezilijenosti tržišta rada Republike Hrvatske na županijskoj razini razmotreno je kroz tri kategorije: zaposlenosti, nezaposlenosti i participacije. Podaci o kretanju ukupne zaposlenosti ${ }^{3}$, participacije ${ }^{4}$ i BDP-a prikupljeni su sa službenih mrežnih stranica Državnog zavoda za statistiku, dok su podaci o kretanju nezaposlenosti $i^{5}$ prikupljeni sa mrežnih stranica Hrvatskog zavoda za zapošljavanje.

\subsection{Metodologija}

U metodološkom određivanju pristupa, autori su se vodili pristupom predstavljenom od strane Faggian et al. (2018), a koji podrazumijeva definiranje odgovora na sljedeća tri pitanja:

- Rezilijentnost „na što“?

- Rezilijentnost "čega“?

- Rezilijentnost "tijekom kojegrazdoblja“?

1. Rezilijentnost "na što”?

Idealno bi bilo procijeniti, ,ukupnu" rezilijentnost ekonomskog sustava na sve moguće vanjske stresore, međutim, uvažavajući dinamičnost i kompleksnost sustava, to je gotovo nemoguće. Stoga, na tragu pristupa u radovima Martin (2012), Martin et al. (2016) i Faggian et al. (2018), proučavali su se učinci ekonomske recesije, ali na primjeru regionalnih tržišta rada u Republici Hrvatskoj. Za Republiku Hrvatsku se razdoblje recesije definira od 2009. do 2014. godine. Posebno je fokus usmjeren na dvije dimenzije reakcije sustava: otpornost tijekom same krize (engl. resistance) i oporavak (engl. recovery) koja pak obuhvaća brzinu oporavka u post-kriznom razdoblju. Prema Martinu (2012) prva predstavlja ranjivost ili osjetljivost sustava na poremećaje poput recesije, dok druga označava brzinu i opseg oporavka nakon šoka.

\footnotetext{
3 Podaci o zaposlenosti obuhvaćaju kretanje ukupnog broja zaposlenih prema administrativnim izvorima, stanje 31. ožujka (podaci Državnog zavoda za statistiku - DZS).

4 Podatatak o participaciji predstavlja odnos između ukupnog broja zaposlenih i nezaposlenih (iz prethodno navedenih izvora) i aktivnog broja stanovništva (predstavljen broj aktivnog stanovništva prema administrativnim izvorima, stanje 31. ožujka (DZS).

5 Podatak o nezaposlenosti obuhvaća kretanje ukupnog broja registriranih nezaposlenih osoba, stanje 31. ožujka (podaci objavljeni od strane DZS, a preuzeti od Hrvatskog zavoda za zapošljavanje - HZZ).
} 


\section{Rezilijentnost „čega"?}

Prilikom utvrđivanja odgovora na navedeno pitanje važno je utvrditi prikladne indikatore, kao i prostorni obuhvat. Kao indikatori kompleksnog tržišta rada, koristit će se podaci o: zaposlenosti, nezaposlenosti i participaciji. Prostorni obuhvat predstavlja 20 županija Republike Hrvatske te grad Zagreb kao samostalna, jedinstvena teritorijalna i upravna jedinica.

3. Rezilijentnost "tijekom kojeg razdoblja "?

Budući da su otpornost i oporavak dvije dimenzije u fokusu interesa ovog istraživanja, potrebno je uzeti u obzir vremensko razdoblje trajanja za obje dimenzije. U Republici Hrvatskoj razdoblje recesije je trajalo od 2009. - 2014. godine, dok je razdoblje oporavka obuhvatilo razdoblje 2014. - 2018., odnosno posljednje godine koja je obuhvaćena ovim istraživanjem. Slijedom navedenog u radu će se koristiti dvije formulacije: za otpornost i za oporavak.

Za otpornost će se koristiti indeks osjetljivosti (engl. sensitivity index - SI) deriviran na temelju radova Martin (2012) i Faggian et al (2018), a koji je sadržan u sljedećem izrazu:

$$
S I_{r t}=\left(\left(\frac{L_{r, t}}{L_{r, t-1}}\right) /\left(\frac{L_{c, t}}{L_{c, t-1}}\right)\right.
$$

gdje Lr predstavlja vrijednost jednog od tri indikatora tržišta rada (zaposlenost, nezaposlenost i ukupna participacija) na županijskoj, a Lc na nacionalnojrazini . Razdoblje t predstavlja zadnju godinu recesije (2014.g.), dok je t-1 predrecesijsko razdoblje (2008.g.).. Za kategoriju zaposlenosti i participacije, vrijednost ovog indeksa iznad 1, znači da je promatrana regija (županija) otpornija u odnosu na cjelokupnu državu, dok vrijednost ispod 1 pokazuje kako je recesija imala jači utjecaj na promatranu regiju (županiju). Kod nezaposlenosti je interpretacija obrnuta.

Druga dimenzija, oporavak (engl. recovery), predstavljena je je indeksom oporavka (engl. recovery index - RI) kroz sljedeći izraz:

$$
R I_{r t}=\left(\left(\frac{L_{r, t}-L_{r, t-1}}{L_{r, t-1}}\right)-\left(\frac{L_{c, t}-L_{c, t-1}}{L_{c, t-1}}\right) /\left(\frac{L_{c, t}-L_{c, t-1}}{L_{c, t-1}}\right)\right.
$$

gdje Lr opet predstavlja vrijednost jednog od tri indikatora tržišta (zaposlenost, nezaposlenost i ukupna participacija) na županijskom, a Lc na nacionalnoj razini, t-1 predstavlja zadnju godinu prije izlaska iz recesije (2014.), a t predstavlja zadnju godinu promatranog post-kriznog razdoblja (2018.). Za vrijednosti zaposlenosti i participacije, vrijednost iznad 1, znači da promatrana regija (županija) bilježi relativno brži oporavak u odnosu na cjelokupnu državu, a vrijednost ispod 1 ukazuje na relativno sporiji oporavak Kod nezaposlenosti je interpretacija suprotna.

Slijedom navedenog potrebno je promatrati rezilijentnost pojedine županije kroz odnos između indeksa osjetljivosti i indeksa oporavka. Na tom tragu su formirane četiri skupine županija u RH za svaki od navedena tri pokazatelja tržišta rada (zaposlenost, nezaposlenost i participacija):

1. Niska otpornost/spor oporavak (Grupa I);

2. Visoka otpornost/brz oporavak (Grupa II);

3. Visoka otpornost/spor oporavak (Grupa III);

4. Niska otpornost/brz oporavak (Grupa IV). 
Pojedina županija pripada skupini s visokom (niskom) otpornošću ukoliko je vrijednost indeksa osjetljivosti veća (niža) od 1 (kod podataka za zaposlenost i participaciju). Pripadnost skupini s brzim (sporim) oporavkom se bilježi ukoliko je vrijednost indeksa oporavka iznad (ispod) 1 (kod podataka za zaposlenost i participaciju). Kod nezaposlenosti je interpretacija suprotna.

\subsection{Rezultati}

\subsubsection{Rezilijentnost zaposlenosti}

Promatrajući rezultate za rezilijentnost zaposlenosti ${ }^{6}$, najbolje vrijednosti (Grupa II) imaju Zadarska županija, Grad Zagreb i Međimurska županija. Grupa III u kojoj je dobra samo jedna dimenzija - otpornost obuhvaća: Dubrovačko-neretvansku, Splitsko-dalmatinsku, Šibenskokninsku, Ličko-senjsku i Varaždinsku županiju, dok grupa IV u kojoj je dobra samo dimenzija oporavka, obuhvaća: Istarsku, Vukovarsko-srijemsku, Zagrebačku i Krapinsko-zagorsku županiju, dok preostalih devet županija bilježi ispodprosječnu vrijednost i otpornosti i oporavka . Iz navedenih rezultata je vidljivo kako županije Jadranske Hrvatske imaju bolje rezultate od županija Kontinentalne Hrvatske. To se može upućivati i na ulogu velike zastupljenosti turističke djelatnosti u Jadranskim Hrvatskoj. Naime, sve županije imaju barem jednu povoljnu dimenziju rezilijentnosti. Što se tiče kontinentalnog dijela Republike Hrvatske, ističe se područje sjeverozapadne Hrvatske, izuzev Koprivničko-križevačke županije. Ovo područje odlikuje geografska pristupačnost europskih eminentnih tržišta. Grad Zagreb s visokim stupnjem urbanizacije te kao gospodarsko i upravno središte Republike Hrvatske ima posebno mjesto, dok. županije s najlošijim rezultatima pretežno pripadaju području Slavonije i Baranje.

Na Grafičkom prikazu 1 je prikazan dijagram rasipanja za kategoriju zaposlenosti s pripadajućim koeficijentom determinacije i ucrtanom linijom regresije. Na osi y nalazi se prva dimenzija rezilijentnosti - otpornost, a na osi x se nalazi druga dimenzija - oporavka.

Grafikon 1. Odnos otpornosti i oporavka među županijama Republike Hrvatske za kategoriju zaposlenosti

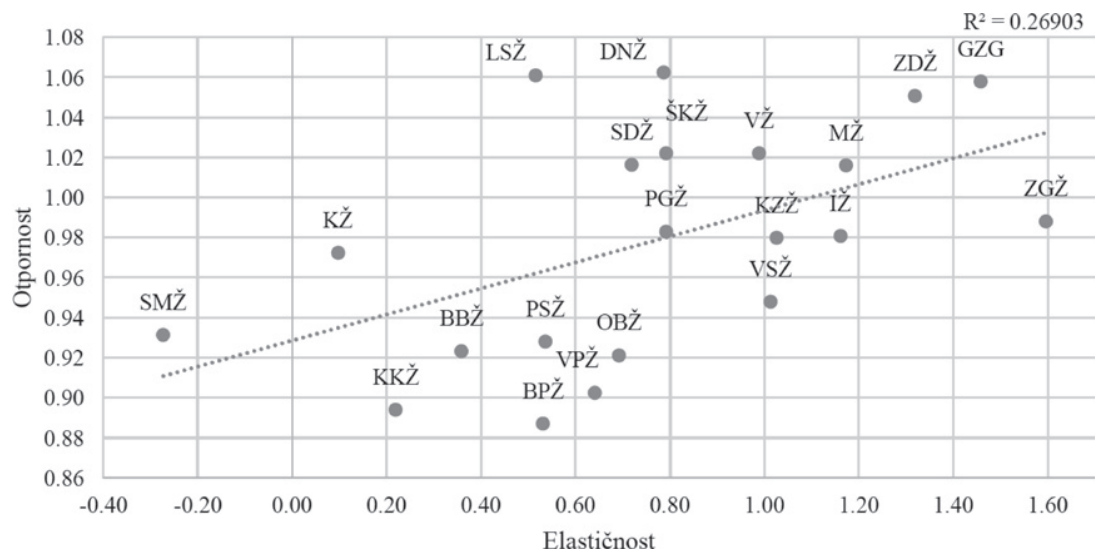

Izvor: obrada autora

${ }^{6}$ Prilog 1. - Tablica 1 
Navedeni grafikon s pripadajućim koeficijent determinacije iznosi 0.26903, odražavajući relativno slabu povezanost oporavka i otpornosti pojedinih regionalnih tržišta rada, odnosno ukazujući na potencijalno različite osobine i faktore utjecaja navedenih dimenzija rezilijentnosti.

\subsubsection{Rezilijentnost nezaposlenosti}

Na temelju podataka za nezaposlenost ${ }^{7}$, među najrezilijentnije županije se svrstavaju: Zadarska, Karlovačka, Brodsko-posavska i Vukovarsko-srijemska županija. Iznadprosječnu otpornost (Grupa III) bilježe: Dubrovačko-neretvanska, Šibensko-kninska, Ličko-senjska, Sisačko-moslavačka, Bjelovarsko-bilogorska, Virovitičko-podravska i Osječko-baranjska županija, dok relativno više razine oporavka (Grupa IV) krase: Istarsku, Primorsko-goransku, Požeško-slavonsku, Zagrebačku, Koprivničko-križevačku, Krapinsko-zagorsku, Varaždinsku i Međimursku županiju te Grad Zagreb. Preostale županije su obilježene i s relativno nižim razinama i otpornosti i oporavka (Grupa I). Promatrajući rezilijentnost na temelju nezaposlenosti, vidljiva je značajna prostorna heterogenost, ali i razlika u odnosu na vrijednosti temeljene na zaposlenosti. Navedeno još jednom ukazuje na svu različitost osnovnih pokazatelja tržišta rada i kompleksnost prilikom donošenja odgovarajućih zaključaka. Navedeno je dodatno pokrijepljeno i grafičkim prikazom 2 koji još jednom ukazuje na različite osobine oporavka i otpornosti pojedinih regionalnih tržišta rada u Hrvatskoj i po pitanju nezaposlenosti.

Grafikon 2. Odnos otpornosti i oporavka među županijama Republike Hrvatske za kategoriju nezaposlenosti

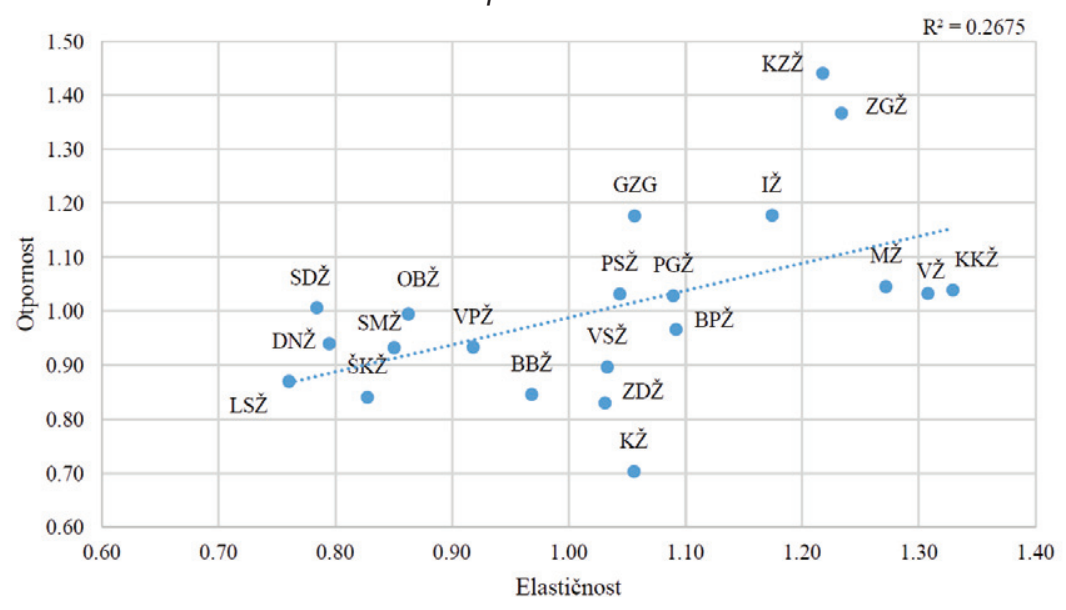

Izvor: obrada autora

7 Prilog 1. - Tablica 2 


\subsubsection{Rezilijentnost participacije}

Naposljetku, razmatrajući rezilijentnost na temelju participacije na županijskim tržištima rada $^{8}$ uočava se iznadprosječna otpornost i oporavak (Grupa II) kod: Dubrovačko-neretvanske, Zadarske, Zagrebačke, Varaždinske županije i Grada Zagreba. Iznadprosječna otpornost krasi: Splitsko-dalmatinsku, Šibensko-kninsku, Ličko-senjsku, Sisačko-moslavačku, Požeškoslavonsku i Bjelovarsko-bilogorsku županiju, dok Istarsku, Primorsko-goransku i Međimursku županiju obilježava iznadprosječni oporavak. Preostalih sedam županija spada u grupu s ispodprosječnim vrijednostima i oporavka i otpornosti (Grupa I). Navedeni rezultati u određenoj mjeri prate rezultate temeljene na zaposlenosti, što je i za očekivati s obzirom na opće zakonitosti tržišta rada. Dodatno, grafički prikaz 3. još jednom ukazuje na relativno značajne razlike regionalnih tržišta rada po pitanju oporavka i otpornosti i kroz kriterij participacije.

Grafikon 3. Odnos otpornosti i oporavka među županijama Republike Hrvatske za kategoriju participacije

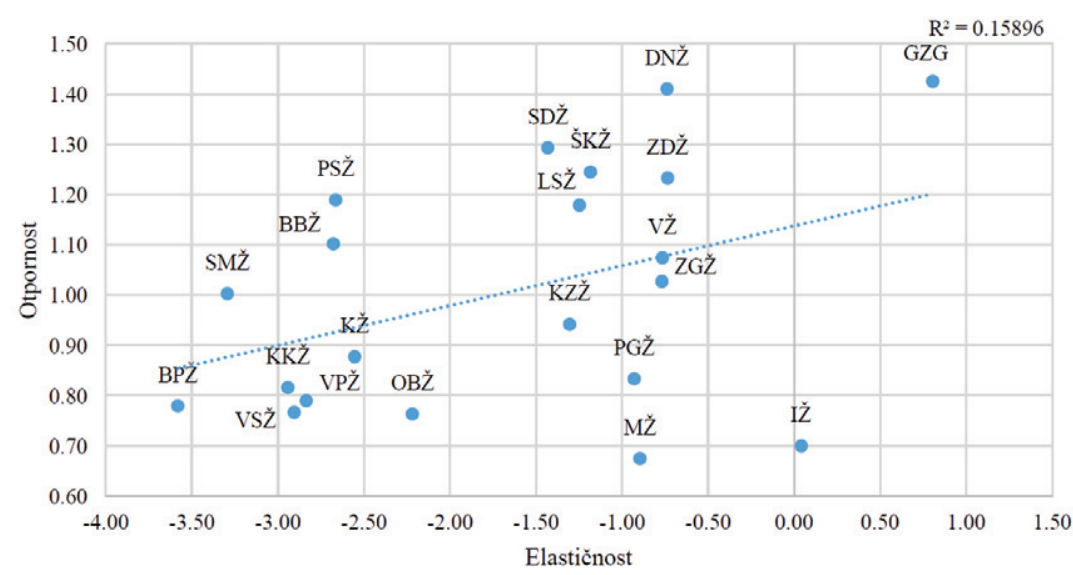

Izvor: obrada autora

Sumirajući rezultate za sve tri kategorije tržišta rada Republike Hrvatske, može se vidjeti izdvojenost Zadarske županije, koja u svim kategorijama bilježi iznadprosječnu i otpornost ii oporavak.

Prisustvo samo iznadprosječne otpornosti, kod sve tri kategorije pokazatelja, je zabilježena samo kod Šibensko-kninske i Ličko senjske županije, dok iznadprosječni oporavak bilježi samo Istarska županija. Sve preostale županije karakterizira iznimna heterogenost i po pitanju oporavka i po pitanju otpornosti. Nadalje, navedeni rezultati obvezuju istraživanje potencijalnih uzorka navedenog stanja, a što ujedno i nadilazi obuhvat ovog rada te predstavlja smjernice za buduća istraživanja.

8 Prilog 1. - Tablica 3. 


\section{Zaključak}

Rezilijentnost je pojam koji je uslijed niza recentnijih šokova promoviran u ekonomskoj znanosti, dok tržište rada najprimjerenije održava svu puninu gospodarskih zbivanja. Premda postojeća literatura ne nudi jedinstven stav po pitanju obuhvata pojma, dominantni pogledi definiraju promatrani fenomen prvenstveno kao sposobnost adekvatne reakcije određenog sustava na različite vrste šokova. Slijedom navedenog, u radu se koristi definicija koja rezilijentnost tržišta rada definira kao sposobnost tržišta rada da se odupre, izdrži ili se oporavi od šoka prilagođavanjem ili preusmjeravanjem svojih resursa i struktura, a s ciljem pospješivanja buduće razvojne perspektive (Bigos et al, 2013).

Između većeg broja različitih dimenzija rezilijentnosti, istraživači interes se posebno fokusirano na otpornosti pojedinih sustava prilikom nastanka šoka, te oporavka, odnosno brzini i intenzitetu oporavka nakon negativnog događaja. Usprkos značajnom interesu međunarodne znanstvene zajednice (npr. Chapple, Lester, 2010; Bigos et al, 2013; Diodato, i Weterings, 2015.), navedeni regionalni aspekti rezilijentnosti tržišta rada u Republici Hrvatskoj su bili zapostavljeni.

Slijedom navedenog u radu su se analizirala županijska tržišta rada u Republici Hrvatskoj u razdoblju 2008-2018. Dimenzija otpornosti se računala za razdoblje 2009.-2013., a oporavka za razdoblje 2014.-2018., predstavljajući osnovu za formiranje četiri grupe županija. Uvažavajući odabrane kategorije tržišta rada (zaposlenost, nezaposlenost i participacija), empirijski rezultati su promovirali Zadarsku županiju kao najrezistentniju županiju u Hrvatskoj. Ujedno su rezultati ukazali na iznadprosječnu otpornost tržišta rada u Šibensko-kninskoj i Ličko-senjskoj županiji, dok iznadprosječni oporavak bilježi samo Istarska županija. Nadalje, heterogenost rezultata kod svih drugih županija u Republici Hrvatskoj upućuje na kompleksnost promatranog fenomena, ali i potrebu za dodatnim istraživanjima prvenstveno usmjerenim na detektiranje ključnih faktora rezilijentnosti, kao i njihovih mehanizama utjecaja.

\section{LITERATURA}

1. Bejaković, P., \& Mrnjavac, Ž. (2018). The danger of long-term unemployment and measures for its reduction: the case of Croatia*. Economic Research-Ekonomska Istraživanja, 31(1), 1837-1850. doi:10.1080/1331677x.2018.1521295

2. Bigos, M., Qaran, W., Fenger, M., Koster, F., Mascini, P., \& Van der Veen, R. (2013). Review essay on labour market resilience. I INSPIRES Project, European Research Area WP, 1., dostupno na poveznici: http://www.inspires-research.eu/userfiles/D1_1\%20Review\%20 Essay\%20on\%20Labour\%20Market\%20Resilience.pdf (pristupljeno 12.3.2020.)

3. Chapple, K., \& Lester, T. W. (2010). The resilient regional labour market? The US case. Cambridge Journal of Regions, Economy and Society, 3(1), 85-104., https://doi.org/10.1093/ cjres/rsp031

4. Diodato, D., \& Weterings, A. B. (2015). The resilience of regional labour markets to economic shocks: Exploring the role of interactions among firms and workers. Journal of Economic Geography, 15(4), 723-742., DOI: 10.1093/jeg/lbu030

5. Državni zavod za statistiku (2020): Zaposlenost i plaće - pregled po županijama, dostupno na poveznici : https://www.google.com/url?sa=t\&rct=j\&q=\&esrc=s\&source=web\&c 
$\mathrm{d}=\&$ ved=2ahUKEwiMwNqpzILwAhVGO-wKHe_uAAgQFjAAegQIBBAD\&url=https\%3A\% 2F\%2Fwww.dzs.hr\%2FHrv_Eng\%2FPokazatelji\%2FZaposlenost\%2520i\%2520place\%2F Zaposlenost\%2520i\%2520place\%2520-\%2520pregled\%2520po\%2520zupanijama.xIsx \&usg=AOvVaw1 eeYUlfJ2bgVrxA1 krB-bH (pristupljeno 12.9.2020.)

6. Faggian, A., Gemmiti, R., Jaquet, T. (2018.). Regional economic resilience: the experience of the Italian local labor systems. Ann Reg Sci 60, 393-410. https://doi.org/10.1007/ s00168-017-0822-9

7. Fingleton, B., Garretsen, H., \& Martin, R. (2015). Shocking aspects of monetary union: The vulnerability of regions in Euroland. Journal of Economic Geography, 15(5), 907-934. https://doi.org/10.1093/jeg/lbu055

8. Giannakis, E. \& Bruggeman, A. (2020) Regional disparities in economic resilience in the European Union across the urban-rural divide, Regional Studies, 54:9, 1200-1213, DOI: 10.1080/00343404.2019.1698720

9. Giacometti, A. i Teräs, J., 2019: 2. Regional Economic and Social Resilience: AnExploratory In-Depth Study in the Nordic Countries. Nordregio: Stockholm, Sweden., dostupno na poveznici: https://nordregio.org/publications/regional-economic-and-social-resiliencean-exploratory-in-depth-study-in-the-nordic-countries/ (pristupljeno 12.5.2020.)

10. Håkansson Gladoić, P; Bejaković, P. (2020). Labour market resilience, bottlenecks and spatial mobility in Croatia // Eastern Journal of European Studies, 11 (2020), 2; 5-25, pristupljeno na poveznici: https://ejes.uaic.ro/articles/EJES2020_1102_HAK.pdf

11. Holling, C. S. (1973). Resilience and stability of ecological systems. Annual review of ecology and systematics, 4(1), 1-23., http://cemi.epfl.ch/files/content/sites/cemi/files/ users/178044/public/Measuring\%20smart\%20specialisation.doc

12. Ledić, M., Rubil, I. (2021).Beyond Wage Gap, Towards Job Quality Gap: The Role of InterGroup Differences in Wages, Non-Wage Job Dimensions, and Preferences. Soc Indic Res (2021). https://doi.org/10.1007/s11205-021-02612-y

13. Martin, R. (2012). Regional economic resilience, hysteresis and recessionary shocks. Journal of economic geography, 12(1), 1-32

14. Martin, R., \& Sunley, P. (2015). On the notion of regional economic resilience: conceptualization and explanation. Journal of Economic Geography, 15(1), 1-42

15. Martin, R., Sunley, P., Gardiner, B., \& Tyler, P. (2016). How regions react to recessions: resilience and the role of economic structure. Regional Studies, 50(4), 561-585

16. Muštra, V.; Šimundić, B.; Kuliš, Z. (2020).Does innovation matter for regional labour resilience? The case of EU regions // Regional Science Policy \& Practice, 12 (2020), 5; 955-970 doi:10.1111/rsp3.12348

17. Nestić, D. \& Tomić, I. (2018) Jobless Population and Employment Flows in Recession, JournalofBalkanandNearEasternStudies,20:3,273-292,DOI:10.1080/19448953.2018.1385271

18. Nestić,D. Babić, Z. \& Blažević Burić, S. (2018) Minimum wage in Croatia: sectoral and regional perspectives, Economic Research-Ekonomska Istraživanja, 31:1, 1981-2002, DOI: 10.1080/1331677X.2018.1473787

19. Nyström, K. (2017). Regional resilience to displacements. Regional Studies, 1-19 
20. Nyström, K., \& Ros, I. V. (2017). Exploring regional differences in the regional capacity to absorb displacements. Geographies of Growth: Innovations, Networks and Collaborations, 19

21. OECD (2012a): What Makes Labour Markets Resilient During Recessions?, OECD Employment Outlook 2012, dostupno na: https://dx.doi.org/10.1787/empl_outlook2012-en

22. OECD (2012b): Better Skills Better Jobs Better Lives. A Strategic Approach to SkillsPolicies, OECD, Paris., dostupno na: https://www.skillsforemployment.org/edmsp1/groups/skills/ documents/skpcontent/mwdf/mda2/ edisp/fm11g_006821.pdf (pristupljeno 12.2.2020.)

23. Simmie, J., \& Martin, R. (2010). The economic resilience of regions: towards an evolutionary approach. Cambridge journal of regions, economy and society, 3(1), 27-43

24. Tomić, I., \& Zilic, I. (2020). Working for 200 Euro? The Unintended Effects of Traineeship Reform on Youth Labor Market Outcomes. LABOUR. doi:10.1111/labr.12176

Summary

\section{RESILIENCE OF REGIONAL EMPLOYMENT, UNEMPLOYMENT AND PARTICIPATION IN THE REPUBLIC CROATIA}

Significant turbulences of the global economy in the recent period have had heterogeneous consequences at the local and regional level. This has been in focus of the scientific community, resulting in the promotion of the concept of resilience as the ability of a particular system to adapt during and after a particular negative shock. The analysis of labor market resilience at the county level in the Republic of Croatia included an analysis of the resistence and elasticity of these markets through the prism of employment, unemployment and participation. Empirical results highlighted Zadar County as the most resistant regional labor market in the Republic of Croatia. At the same time, the heterogeneity of the remaining results pointed to the complexity of labor market relations, as well as the clear need for further research.

Keywords: resilience, employment, unemployment, participation, regions, Republic of Croatia. 


\section{Prilozi}

Tablica 1. Vrijednosti indeksa osjetljivosti (otpornosti) i indeksa oporavka (oporavak) podaci za zaposlenost

\begin{tabular}{|l|c|c|}
\hline Županije & SI (Otpornost) & RI (Elastičnost) \\
\hline Zagrebačka & 0.99 & 1.60 \\
\hline Krapinsko-zagorska & 0.98 & 1.03 \\
\hline Sisačko-moslavačka & 0.93 & -0.27 \\
\hline Karlovačka & 0.97 & 0.10 \\
\hline Varaždinska & 1.02 & 0.99 \\
\hline Koprivničko-križevačka & 0.89 & 0.22 \\
\hline Bjelovarsko-bilogorska & 0.92 & 0.36 \\
\hline Primorsko-goranska & 0.98 & 0.79 \\
\hline Ličko-senjska & 1.06 & 0.52 \\
\hline Virovitičko-podravska & 0.90 & 0.64 \\
\hline Požeško-slavonska & 0.93 & 0.54 \\
\hline Brodsko-posavska & 0.89 & 0.53 \\
\hline Zadarska & 1.05 & 1.32 \\
\hline Osječko-baranjska & 0.92 & 0.69 \\
\hline Šibensko-kninska & 1.02 & 0.79 \\
\hline Vukovarsko-srijemska & 0.95 & 1.01 \\
\hline Splitsko-dalmatinska & 1.02 & 0.72 \\
\hline Istarska & 0.98 & 1.16 \\
\hline Dubrovačko-neretvanska & 1.06 & 0.79 \\
\hline Međimurska & 1.02 & 1.17 \\
\hline Grad Zagreb & 1.06 & 1.46 \\
\hline
\end{tabular}

Tablica 2. Vrijednosti indeksa osjetljivosti (otpornosti) i indeksa oporavka (oporavak) podaci za nezaposlenost

\begin{tabular}{|l|c|c|}
\hline Županije & SI (Otpornost) & RI (Elastičnost) \\
\hline Zagrebačka & 1.37 & 1.23 \\
\hline Krapinsko-zagorska & 1.44 & 1.22 \\
\hline Sisačko-moslavačka & 0.93 & 0.85 \\
\hline Karlovačka & 0.70 & 1.06 \\
\hline Varaždinska & 1.03 & 1.31 \\
\hline Koprivničko-križevačka & 1.04 & 1.33 \\
\hline Bjelovarsko-bilogorska & 0.85 & 0.97 \\
\hline Primorsko-goranska & 1.03 & 1.09 \\
\hline Ličko-senjska & 0.87 & 0.76 \\
\hline Virovitičko-podravska & 0.93 & 0.92 \\
\hline
\end{tabular}




\begin{tabular}{|l|c|c|}
\hline Županije & SI (Otpornost) & RI (Elastičnost) \\
\hline Požeško-slavonska & 1.03 & 1.04 \\
\hline Brodsko-posavska & 0.97 & 1.09 \\
\hline Zadarska & 0.83 & 1.03 \\
\hline Osječko-baranjska & 0.99 & 0.86 \\
\hline Šibensko-kninska & 0.84 & 0.83 \\
\hline Vukovarsko-srijemska & 0.90 & 1.03 \\
\hline Splitsko-dalmatinska & 1.01 & 0.78 \\
\hline Istarska & 1.18 & 1.17 \\
\hline Dubrovačko-neretvanska & 0.94 & 0.79 \\
\hline Međimurska & 1.05 & 1.27 \\
\hline Grad Zagreb & 1.18 & 1.06 \\
\hline
\end{tabular}

Tablica 3. Vrijednosti indeksa osjetljivosti (otpornosti) i indeksa oporavka (oporavka) podaci za participaciju

\begin{tabular}{|l|c|c|}
\hline Županije & SI (Otpornost) & RI (Elastičnost) \\
\hline Zagrebačka & 1.03 & 0.77 \\
\hline Krapinsko-zagorska & 0.94 & 1.30 \\
\hline Sisačko-moslavačka & 1.00 & 3.29 \\
\hline Karlovačka & 0.88 & 2.55 \\
\hline Varaždinska & 1.07 & 0.76 \\
\hline Koprivničko-križevačka & 0.82 & 2.94 \\
\hline Bjelovarsko-bilogorska & 1.10 & 2.68 \\
\hline Primorsko-goranska & 0.83 & 0.93 \\
\hline Ličko-senjska & 1.18 & 1.25 \\
\hline Virovitičko-podravska & 0.79 & 2.83 \\
\hline Požeško-slavonska & 1.19 & 2.66 \\
\hline Brodsko-posavska & 0.78 & 3.58 \\
\hline Zadarska & 1.23 & 0.74 \\
\hline Osječko-baranjska & 0.76 & 2.22 \\
\hline Šibensko-kninska & 1.24 & 1.18 \\
\hline Vukovarsko-srijemska & 0.77 & 2.91 \\
\hline Splitsko-dalmatinska & 1.29 & 1.43 \\
\hline Istarska & 0.70 & -0.04 \\
\hline Dubrovačko-neretvanska & 1.41 & 0.74 \\
\hline Međimurska & 0.68 & 0.90 \\
\hline Grad Zagreb & 1.42 & -0.80 \\
\hline
\end{tabular}

